\title{
Utilization of Shredded Waste Car Tyres as a Fracture Seal Material (FSM) in Oil and Gas Drilling Operations
}

\section{Musaed NJ Al-Awad ${ }^{1 *}$ and Fattah KA ${ }^{1,2}$}

${ }^{1}$ Department of Petroleum and Natural Gas Engineering, College of Engineering, King Saudi University, Riyadh, Saudi Arabia ${ }^{2}$ Faculty of Engineering, Department of Petroleum Engineering, Cairo University, Cairo, Egypt

\begin{abstract}
The drilling operation cost represents $25 \%$ of the total oilfield exploitation cost. Drilling fluids represent 15 to $18 \%$ of the total cost of well petroleum drilling operations. The main drilling fluids problem is the loss into fractures and vugs. Mitigation of severe lost circulation is a main challenge while drilling in fractured formations where conventional lost circulation materials (LCM) will not cure these losses. Therefore, specialized fracture seal material (FSM) is required when drilling fractured formations.

In this study, a promising FSM made from shredded waste car tyres was tested at laboratory for its ability to seal artificially fractured cores under High Temperature High Pressure (HT-HP) conditions similar to wellbore conditions. For this purpose, the conventional $500 \mathrm{ml} \mathrm{HT-HP}$ filtration cell was modified to accommodate a fractured core plug of length and diameter equal to $38.1 \mathrm{~mm}$ (1.5 inches) instead of the ceramic disc. Moreover, the cell outlet channel located below the fractured plug was increased from $1.0 \mathrm{~mm}$ diameter to $5.0 \mathrm{~mm}$ to easily allow the passage of the FSM in none effective fracture seal tests.

Using the modified HT-HP filtration cell shredded waste car tyres proved its ability to perfectly seal the artificially made fracture in the test core samples at overbalance pressures up to $900 \mathrm{psi}$ and temperatures up to $80^{\circ} \mathrm{C}$. The optimum mud composition was fresh water, $7 \%$ by weight bentonite, $7 \%$ shredded waste car tyres (a mixture ranging between $2.3 \mathrm{~mm}$ and less than $0.45 \mathrm{~mm}$ granule sizes) in weight bases.

In addition to its great ability to seal fractured formation, the shredded waste car tyres material is cheap and locally available in commercial quantities. Additionally, the utilization of waste car tyres in drilling operations and other industrial applications can protect the environment from many hazards.
\end{abstract}

Keywords: Waste; Oil; Gas; Drilling

\section{Introduction}

Routine drilling fluids filtration measurements are performed on a filter paper using either the API filter press $\left(100\right.$ psi and $\left.25^{\circ} \mathrm{C}\right)$ or HT-HP filter press (175 ml or $500 \mathrm{ml})$. Additionally, HT-HP filtration can be performed on a ceramic disc. Filter papers or ceramic discs are normally used to simulate mud filtration through rock matrix in non-fractured formations. Several attempts have been performed to investigate the effect of various LCM and FSM on sealing fractured formations. Mark W. Sanders and Oscar Contreras experimentally studied the mechanisms of lost circulation materials (LCM) seal of induced fractures in thick-wall cylindrical cores [1,2]. Arunesh Kumar developed a tapered slot to physically resembling a wedge-shaped fracture for testing various types of LCM [3].

Matthew L. Miller developed a low-volume, laboratory-scale apparatus with multiple configurations to better model lost circulation conditions encountered while drilling through vugular and fractured zones [4]. The apparatus has a high working pressure and high pressure differentials can be used to test plugs formed by lost circulation materials.

Hong (Max) Wang used boundary element analysis (BES) to theoretically investigate the process of cracks sealing to strengthen the wellbore [5]. They concluded that perfect sealing of cracks enhances wellbore stability. In a recent study, Kuhan Chellappah a real attempt was done to simulate fractured formation by replacing the ceramic disc in the HT-HP filter press by slotted stainless steel [6].

Amanullah used crushed palm date seeds as a fracture seal material (FSM) for sealing fractured formations [7]. In his study, he used 2.0 $\mathrm{mm}$ slotted stainless steel discs fitted into a standard $250 \mathrm{~mm}$ HT-HP filtration cell to test the possibility of fracture seal by a drilling fluid containing the crushed palm date seeds. The result was a perfect fracture seal indicating the possibility of utilizing this material in drilling oil and gas wells. One of the drawbacks of this study is that the outlet valve only designed to allow mud filtrate to pass rather than the FSM. Therefore, it cannot be distinguished between the fracture seal of the outlet valve plugging.

Al-Awad and Fattah used crushed palm date seeds as a fracture seal material (FSM) for drilling fractured formations. In their study, they used fractured rock discs fitted into modified $500 \mathrm{~mm}$ HT-HP filtration cell to test the possibility of fracture seal by a drilling fluid containing the crushed palm date seeds [8]. The result was a perfect fracture seal indicating the possibility of utilizing this FSM when drilling oil and gas wells located in fractured formations.

\section{Objectives of the Study}

The objectives of this study are of three folds as follows:

*Corresponding author: Musaed NJ Al-Awad, Department of Petroleum and Natural Gas Engineering, College of Engineering, King Saud University, Riyadh, Saudi Arabia, Tel: +966-11-4676879; E-mail: malawwad@ksu.edu.sa

Received March 21, 2017; Accepted April 24, 2017; Published April 30, 2017

Citation: Al-Awad MNJ, Fattah KA (2017) Utilization of Shredded Waste Car Tyres as a Fracture Seal Material (FSM) in Oil and Gas Drilling Operations. J Pet Environ Biotechnol 7: 322. doi: 10.4172/2157-7463.1000322

Copyright: (c) $2017 \mathrm{Al}-\mathrm{Awad} \mathrm{MNJ}$, et al. This is an open-access article distributed under the terms of the Creative Commons Attribution License, which permits unrestricted use, distribution, and reproduction in any medium, provided the original author and source are credited. 
Citation: Al-Awad MNJ, Fattah KA (2017) Utilization of Shredded Waste Car Tyres as a Fracture Seal Material (FSM) in Oil and Gas Drilling Operations. J Pet Environ Biotechnol 7: 322. doi: 10.4172/2157-7463.1000322

Page 2 of 4

1. Testing of shredded waste car tyres for utilization as a fracture seal material in oil and gas wells drilling operation. Shredded and granulated waste car tyres are utilized in a wide range of applications, including carpet underlay, road building, all-weather training areas for horses, playgrounds, rubber matting, sports and recreational surfaces. This study is aimed to find a promising fracture seal material for use in oil and gas wells drilling operations. There are numerous materials available in the market for fracture seal applications; however; the utilization of shredded waste car tyres has many advantages such as

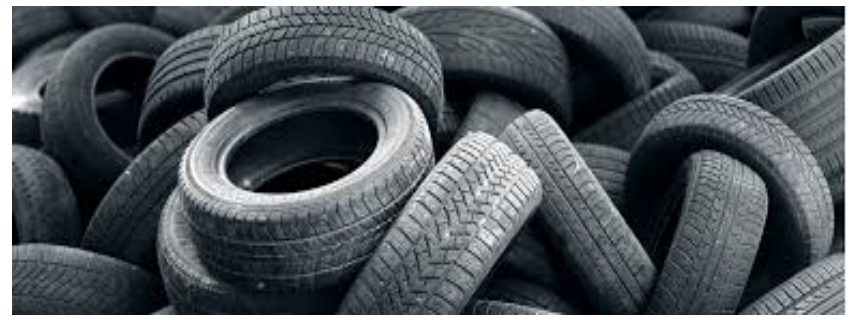

Figure 1: Discarded car tyres.
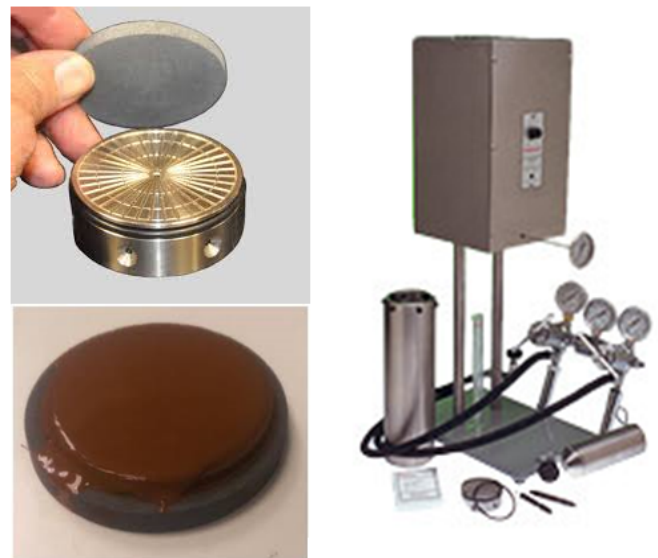

Figure 2: HT-HP filter press $(500 \mathrm{ml})$.

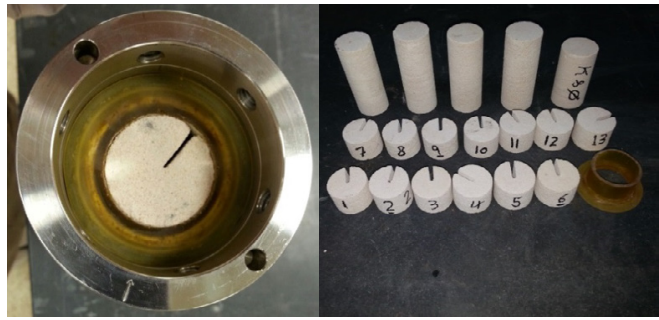

Figure 3: The developed core holder and the testing cores.

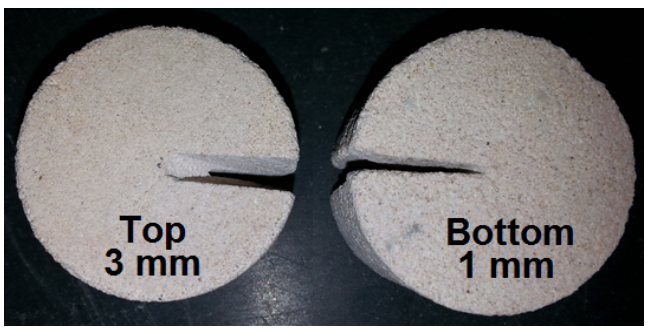

Figure 4: Sandstone core plug with artificial fracture.

\begin{tabular}{|c|c|}
\hline Properties & Measured Values \\
\hline Rock Type & Artificial White Sandstone \\
\hline Porosity & $30 \%$ \\
\hline Permeability & $266 \mathrm{md}$ \\
\hline Unconfined Compressive Strength & $14 \mathrm{M} \mathrm{Pa}$ \\
\hline Tensile Strength & $2.7 \mathrm{MPa}$ \\
\hline Plug Diameter & $38.1 \mathrm{~mm}(1.5 \mathrm{inches})$ \\
\hline Plug Length & $38.1 \mathrm{~mm}(1.5$ inches $)$ \\
\hline Fracture Top & $3.0 \mathrm{~mm}$ \\
\hline Fracture Bottom & $1.0 \mathrm{~mm}$ \\
\hline Fracture Length & $38.1 \mathrm{~mm}(1.5 \mathrm{inches})$ \\
\hline
\end{tabular}

Table 1: Properties of the utilized sandstone plugs.
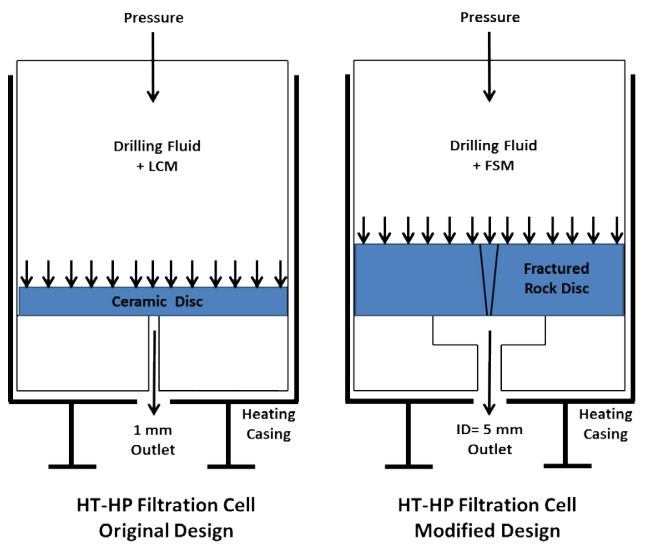

Figure 5: Sketch showing the modification in the cell core holder cap

reducing environmental hazards. A large pile of discarded tyres (Figure 1) can quickly turn into a dangerous fire that is difficult to extinguish causing extraordinary air pollution.

2. Modifying of the standard API HT-HP filtration apparatus (Figure 2) normally used with ceramic disk for fracture seal tests applications. This standard testing apparatus is designed to measure the filtration of drilling fluids through a manufactured ceramic disc. The outlet valve is designed to only allow mud filtrate and very fine particles (clay size) flow. In this work, this apparatus was modified to accommodate an artificially fractured rock disc as shown in Figure 3. Furthermore, the outlet of the cell was increased to allow flow of fluid with large particles in case of non-perfect seal of the fracture in the test rock disc to avoid false results if the original valve is used.

3. Developing a new method for artificial fracture generation in rock cores (plugs) to replace the stainless slotted disc (Figure 3) where the filtration process is impossible. To simulate natural fractured rocks, core plugs of $38.1 \mathrm{~mm}$ diameter and $38.1 \mathrm{~mm}$ thickness were cored from an artificial sandstone blocks. The properties of this sandstone are shown in Table 1. After coring and trimming to the required dimensions, a single fracture was performed in each core with an opening (top) size of $3.0 \mathrm{~mm}$ until half way of the core length, then a tip (bottom) size of $1.0 \mathrm{~mm}$ along the remaining thickness up to the bottom of the core as shown in Figure 4. The advantage of this fractured core among the stainless steel slotted disc is that both LCM (bentonite) in the base mud as well as the FSM additive contribute to the developed seal as well in the fractured and non-fractured parts of the core plug. Figure 5 shows a sketch of the modified core holder cap. 


\section{Experimental Work}

\section{FSM preparation}

The preparation of FSM from the car waste tyres was performed by applying the following steps:

1. Waste care tyres are shredded into small pieces suitable for used in the grinding machine. Steel wires are removed out and the result is pure rubber particles.

2. The rubber cubes are placed in liquid nitrogen to freeze it and make it possible for crushing into granules using the crushing machine.

3. Sieving analysis is performed to identify the required rubber granules suitable for the designed fracture size (Figures 6 and 7).

\section{Fracture seal tests}

The following procedure was precisely followed during testing the FSM made from car waste tyres:

a) Prepare the required mud by mixing $7 \%$ by weight bentonite and the required FSM (a mixture ranging between $2.3 \mathrm{~mm}$ and less than $0.45 \mathrm{~mm}$ granule sizes) in fresh water in mud mixer for 10 minutes.

b) Perfectly fit the test core plug into the rubber sleeve using temperature resistant adhesive tap where the fracture opening is facing the drilling fluid side as shown in Figure 8.

c) Pure the mixed mud into the $500 \mathrm{ml}$ HT-HP filter press cell and place the sleeve over the O-ring then fit the cell cover and firmly tight the six screws.

d) Place the cell up-side-down in the heating casing and wait until reaching the required temperature $\left(80^{\circ} \mathrm{C}\right)$.

e) Open the nitrogen cylinder valve to apply the required pressure difference on the top of the mud.

f) Open the bottom valve at atmospheric pressure $(\Delta \mathrm{P}=200 \mathrm{psi})$ and record spurt volume as well as filtrate volume with time.

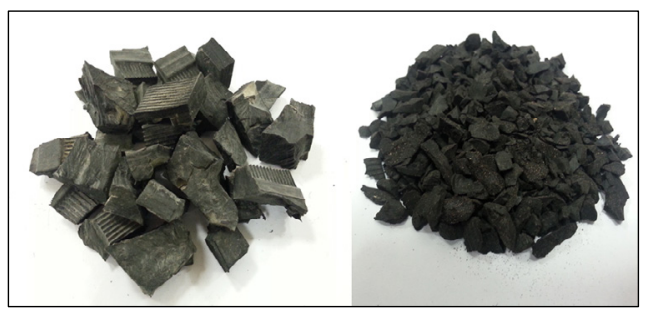

Figure 6: Care waste tyres pieces before and after crushing

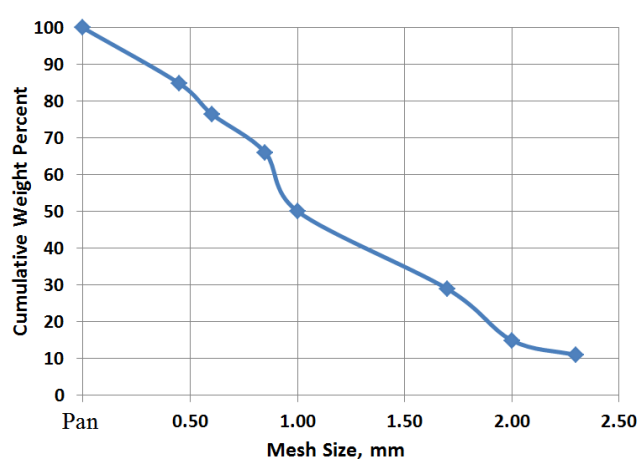

Figure 7: Granulometric analysis of the FSM.

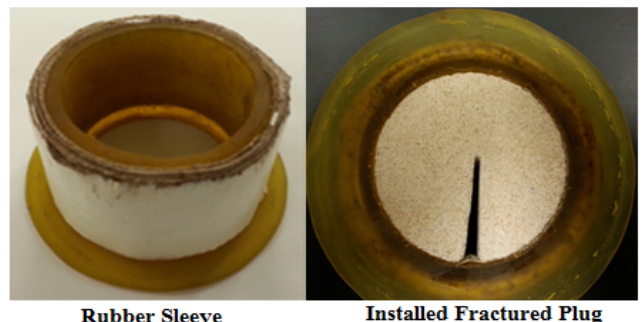

Figure 8: The developed rubber sleeve with temperature resistant adhesive tap.

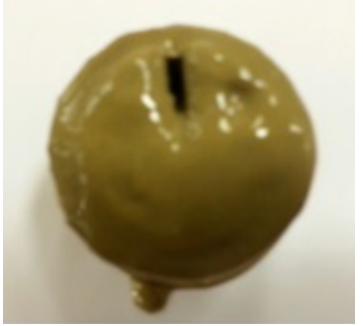

Figure 9: Top view of the fractured sandstone core plug at the end of the experiment no. 1 .
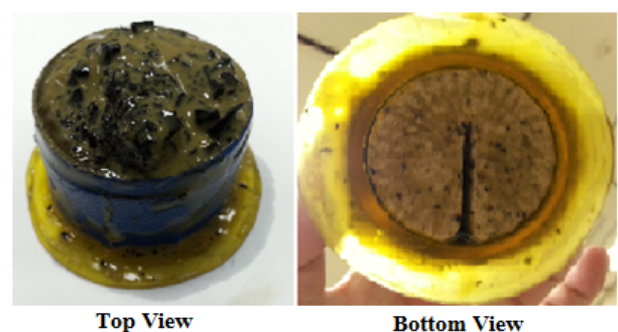

Figure 10: Top and bottom views of the fractured sandstone core plug. at the end of the experiment no. 2 .

g) Increase the inlet pressure gradually up to 900 psi to examine the fracture seal integrity.

h) At the end of the test, leave the cell to cool to laboratory temperature, then release the cell pressure and extract the core plug for inspection.

The experimental design (mud composition and FSM type and concentration, temperature, pressure difference, and experiments replication) is used for the verification of the potential use of FSM to seal fractured formations while drilling.

\section{Results and Discussion}

In the first experiment, a base mud (fresh water $+7 \%$ bentonite by weight) without LCM or FSM was tested for its potential ability for fracture sealing at pressure difference of $200 \mathrm{psi}$ and $21^{\circ} \mathrm{C}$ (laboratory temperature). The result was a complete loss of the mud within one minute. The inspection of the core plug after the test showed that a mud cake has formed and sealed only the core matrix while the fracture is remaining completely open as shown in Figure 9. This result indicated the need for a FSM to seal this fractured rock.

In the second experiment 7\% FSM made from the shredded waste car tyres is added to the based mud. The result was a perfect seal after 5 minutes with a $20 \mathrm{cc}$ spurt and $5 \mathrm{cc}$ filtration loss under 200 psi pressure drop and $80^{\circ} \mathrm{C}$. After the development of the complete seal, the pressure 
Citation: Al-Awad MNJ, Fattah KA (2017) Utilization of Shredded Waste Car Tyres as a Fracture Seal Material (FSM) in Oil and Gas Drilling Operations. J Pet Environ Biotechnol 7: 322. doi: 10.4172/2157-7463.1000322

Page 4 of 4

drop was gradually increased up to a maximum value of 900 psi to check the seal integrity with full success (Figure 10).

It is worth to say that this FSM has an important property among other solid FSM which is elasticity. Due to rubber elasticity, the FSM is able to enter the facture and move forward until the narrowest pat of the fracture driven by the mud pressure.

Therefore, the optimum mud (fresh water $+7 \%$ bentonite $+7 \%$ FSM made from shredded waste car tyres in weight bases) used in this study proved its ability to seal the tested fracture perfectly up to $900 \mathrm{psi}$ pressure difference and $80^{\circ} \mathrm{C}$ temperature.

\section{Conclusions}

Based on the analysis performed in this study, the following conclusions can be made:

1. The HT-HP $500 \mathrm{ml}$ filter press has been modified to accommodate real core sample of $38.1 \mathrm{~mm}$ diameter and $38.1 \mathrm{~mm}$ length with an artificially made fracture. Furthermore, the cell outlet diameter was increased to allow the passage of the used FSM in case of none sealed fracture.

2. An optimum mud (fresh water $+7 \%$ bentonite $+7 \%$ FSM made from a mixture of shredded waste car tyres in weight bases ranging between $2.3 \mathrm{~mm}$ and less than $0.45 \mathrm{~mm}$ granule sizes) perfectly sealed an artificial fracture of $3 \mathrm{~mm}$ top and $1 \mathrm{~mm}$ bottom made in a sandstone core sample of $38.1 \mathrm{~mm}$ diameter and 38.1 length.

3. FSM made from shredded waste car tyres proved its great ability to seal the tested fractured core plugs at temperatures and pressures up to $80^{\circ} \mathrm{C}$ and 900 psi respectively.

\section{References}

1. Sanders MW, Young S, Friedheim J (2008) Development and testing of novel additives for improved wellbore stability and reduced losses. AADE-08-DFHO-19, A paper prepared at the 2008 AADE Fluids Conference and Exhibition, Houston, Texas.

2. Contreras O, Hareland G, Husein M, Nygaard R, Alsaba M (2014) Wellbore strengthening in sandstones by means of nanoparticles-based drilling fluids. A paper presented at the SPE deep water drilling and completions conference, Galvestone, Texas, USA.

3. Kumar A, Savari S (2011) Lost circulation control and wellbore strengthening Looking beyond particle size distribution. AADE-11-NTCE-21, A paper presented at the 2011 AADE National Technical Conference and Exhibition, Houston, Texas.

4. Miller ML, Jamison D, Murphy RJ (2013) Laboratory apparatus improves simulation of lost circulation conditions. AADE-13-FTCE-09, A presented at the 2013 AADE National Technical Conference and Exhibition, Oklahoma City.

5. Wang H, Towler BF, Soliman M (2007) Fractured wellbore stress analysis: Sealing cracks to strenghten a wellbore. A paper presented at the 2007 SPE/ IDAC Drilling Conference, Amsterdam, The Netherlands.

6. Chellappah K, Kumar A, Aston M (2015) Drilling depleted sands: Challenges associated with wellbore strengthening fluids. A paper presented at the SPE/ IDAC drilling conference, London, UK.

7. Amanullah M (2016) Characteristics, behavior and performance of ARC plug- A date seed-based sized particulate LCM. SPE paper no. 182840-MS presented at the SPE-KSA Annual Technical Symposium and Exhibition held in Dammam, Saudi Arabia.

8. Al-Awad M, Fattah KA (2017) Superior fracture seal material using crushed date palm seeds for oil and gas well drilling operations. Journal of King Saud University-Engineering Sciences (JKSUES), Saudi Arabia. 